\title{
Opal fuel reduces gas-sniffing and suicides in Australia
}

$\mathrm{T}$ he email that changed everything for the Aboriginal community of Papunya, Australia, arrived in Mark Glazebrook's personal inbox at BP Australia:

"As I write this email, I am looking at an 11-year-old girl out the window with half a Coke bottle over her nose and mouth, sniffing petrol. I don't know whether she's going to reach her 12th birthday. Can you help?"

It was March 2002. The email was from Chris Tangey, a youth worker with an $\mathrm{Ab}$ original media organization based in Alice Springs, Australia. Tangey had recently returned to Papunya, where he found his beautiful, bright students of the year before staggering around "like zombies," he remembers. They were addicted to sniffing gas.

Of the 250 people who lived in Papunya, about a third, aged 8 to 25 , were sniffing fuel. "Many had been badly burned after combining cigarettes with their fuel habit. Others had simply given up and committed suicide," Tangey says. Suicides made up a quarter of all the deaths associated with gassniffing in Central Australia from 1998 to 2003, according to the Menzies School of Health Research.

The email Tangey sent to 10 different oil companies was a desperate appeal that he was convinced would not work.

He was wrong.

His email eventually sparked a transformation in more than 50 Australian indigenous communities that were losing their children and teens to gas-sniffing and suicide - an all-toofamiliar tragedy in the lives of many
Inuit and First Nations youth halfway across the world in Canada.

The woman who checked the BP's general inquiry inbox was so moved by

receptive audience. Glazebrook was studying a series of reports from coroner's inquests into suicides and other deaths associated with sniffing gas. Reading Tangey's plea for help was the push BP needed.

"It just hit us at a human level," Glazebrook said in an interview with CMAJ. "It wasn't something we could ignore. It's something about the culture of BP - we're sons and daughters, we're parents, and it struck too some national pride to say 'We can't really allow this sort of thing to happen in Australia,' and if it's something to do with what we're skilled at, which is the production of fuel, then surely we should take some role in reducing the problem."

Glazebrook's first step was to travel with Tangey and another BP manager to Papunya, to see the problem first-hand. The day they arrived, a 14-year-old who routinely sniffed gas had hanged himself from Papunya's water tank.

"You could see the rope still hanging off the water tank," says Glazebrook.

Other young people were living on the margins of the community, as if they were animals or second-class citizens, Glazebrook recalls. One 11-year-old who routinely sniffed gas was living in an abandoned car, feeding him-

Tangey's simple plea that she phoned him within the hour, in tears, and promised to get his message to the company's chief executive officer.

When the CEO passed the email along to Glazebrook, BP's manager of corporate responsibility, he found a self out of a garbage bin.

Tangey believes what he calls a "tragic exclamation mark" turned Glazebrook and his colleague "from businessmen on a company visit to human beings on a mission."

Glazebrook turned to BP's chemists 
for help. Could they change their fuel's formula so it still performed well in vehicles, but didn't have the same hallucinogenic properties?

They could. Three years after Tangey's powerful plea, in 2005, BP Australia launched Opal, a high-performance fuel without the low aromatic compounds that produce a high when sniffed.

Today, with the help of Australia's health department, the company distributes 25 million litres of Opal annually to more than 110 roadhouses, regional hubs and remote communities where gas-sniffing was an endemic problem. Recently, Shell agreed to distribute the fuel to the communities it serves as well.

Australia's government has spent more than $\$ 86$ million since 2005 subsidizing the additional production, storage, and transportation costs of producing Opal, so consumers pay the same for Opal as they do for regular unleaded fuel.

The prevalence of gas-sniffing in those communities, on average, has now dropped by $70 \%$ to $90 \%$, according to several studies. In the communities served by the Central Australian Youth
Link Up Service, including Papunya, gas-sniffing had dropped by $94 \%$ by 2011, according to the organization's report to a parliamentary committee.

"It is also our experience that the drop in prevalence of petrol sniffing has been complemented by an overall drop in levels of suicide attempts that our service deals with," the organization wrote. "However prevalence of youth suicide and threats of suicide remain a major issue in our communities and are often closely connected to use of cannabis and alcohol."

In other words, Opal alone is not the answer to youth suicide. The Australian government's simultaneous investment in more youth programs and workers in Papunya and other remote communities is also critical, says Glazebrook. Those programs give the youth healthy activities and bolster food security and education.

"A fuel solution like Opal can only ever be part of the solution," he says. "It doesn't take away the root causes of why kids would be sniffing in the first place."

What Opal has done, however, is ensured that families, social services workers and health care providers can work more effectively because they are not in crisis mode. In Papunya, once youth learned they could not get high off Opal, they stopped sniffing. They reconnected with their families and began to embrace their community's traditional ceremonies.

In 2012, Glazebrook returned to Papunya with his family, for a vacation. He was amazed by the changes in the community. Gone were the high fences topped with barbed wire that had been erected to protect fuel tanks and vehicles from having their gas siphoned. Classrooms were again full.

Best of all, former sniffers like Gavin Bush, who participated in a video that $\mathrm{BP}$ produced about Opal, are now doing valuable volunteer work for the community.

"To my mind that's an incredibly great outcome," says Glazebrook. "I feel very proud." - Laura Eggertson, Ottawa, Ont.

CMAJ 2014. DOI:10.1503/cmaj.109-4756 